i berøring med, et meget værdifuldt arbejde. Det har givet os et nyt, til en vis grad også et ændret billede af en omstridt mand. $\mathrm{Og}$ det sætter væsentlige tanker i gang om, hvad det grundtvigske er.

\title{
Grundtvig og den middelalderlige kontemplative tradition.
}

\author{
Af Kim Arne Pedersen
}

Jørgen Pedersen: Prior omnium sapientia. Om visdomsbegrebet og visdomsidealet i Augustins hovedskrifter I-II, Dansk Teologisk Tidsskrift 51. ding. 1988. Visdommens Veje. Fire skrifter af Bonaventura oversat med et indførende essay af Jørgen Pedersen. Kbh. 1991. Jørgen Pedersen: Fra Augustin til Johs. V. Jensen, Essays og afhandlinger. Kbh 1991.

Blandt danske teologer skiller Jørgen Pedersen sig ud, ikke blot ved sin uhyre lærdom, men også ved at knytte til ved teologi-og idehistoriske traditioner, der sjældent optræder i en dansk, teologisk sammenhæng. Er man som læser skolet i den eksistential-fænomenologiske, filosofiske og teologiske hermeneutik, virker Jørgen Pedersens ubesværede og direkte tilgang til epokerne og deres fælles ideindhold fremmed, men også fascinerende, båret af en trang til fuldstæendighed, der båder skræmmer og tiltrækker.

Laserens tilegnelse af stoffet vanskeliggøres også af, at afhandlingerne er skrevet $\mathrm{i}$ et tungt og kompliceret sprog, hvor Jørgen Pedersens fuldstændighedsideal fører ham til at lade hver enkelt sætning rumme så megen information som muligt. Navnes en tænker, skal forbindelserne til hele den europæiske åndshistorie med det samme trækkes op.

Jørgen Pedersen betoner kontinuiteten i den europæiske tænkning, og han kan se sammenhange mellem de forskelligste forfatterskaber fra antikken til det 20. århundrede. Spredt i forfatterskabets forskellige afhandlinger - men udførligst fremstillet i afhandlingen Den dybe sammenhaeng i Fra Augustin til Johs. $V$. Jensen - finder vi en rakke studier i Grundtvigs salmedigtning, der ifølge Jørgen Pedersen selv beres af den intention at vise, at whvor Grundtvig er mest "grundtvigst « eller lyder som sådan, er han tillige mest trofast middelalderlig og som digter ogsd oversætter (Fra Augustin, 171). Og i kraft af denne intention tykkes det Jørgen Pedersen at tilføre Grundtvig-forskningen nye og overraskende indsigter ved at føje Grundtvigs forfatterskab ind i den augustinske tradition.

Jørgen Pedersen formår at forene sin omfattende læsning af primærlitteratur fra hele den europæiske åndshistorie med indsigter fra katolsk middelalderforskning og tyske, angelsaksiske og franske idehistoriske studier $i$ især romantikkens vasen. Ét navn og én strømning går igen i alle hans studier: Augustin og augustinismen, bærere af en linje i vesteuropæisk tænkning, der forener religiøs in- 
derlighed, vished og metafysisk erkendelsestrang, i og med, at »det er i et indre og indirekte forhold, at den samme Guds Visdom eller Tanke, ved hvilken Verden er skabt, også for den menneskelige tanke begrunder dens vished og dens erkendelses form og mål (Fra Augustin 194). Jørgen Pedersen fremhæver den augustinske betoning af den menneskelige ånds numiddelbare og indre forhold til den transcendent nærværende absolutte sandhed, af hvis lys den som gudsbillede altid omfattes og berøres* (Visdommens veje, 53), idet han fremhæver, at denne augustinske $\star k r i s t o c e n t r i s m e_{\kappa} i$ sin syntese omfatter samtlige »subjektive, ...illuminative,...emotionelle..kulturelt-videnskabelige « naspekter * (Visdommens veje, 55). Væsentligt er det forhold, at den augustinske illuminatio-lære, forestillingen om, at den menneskelige sjæl erkender i og gennem Guds virke i sjælen, formidler mellem det individuelle og den metafysisk forståede, absolutte sandhed. Jørgen Pedersen skriver, at DDen subjektivitet, der knytter sig til det indre sandhedsforhold, forklaret ved visdommen som sjælens lys, er...balanceret og objektivt orienteret ved sin uopløselige sammenhæng med den eksemplaristiske skabelseslære på den ene side og inkarnationen som frelsesvej på den andenk (Visdommens veje, 55).

Jørgen Pedersen interesserer sig da i særdeleshed for at vise, hvorledes det indre og det ydre $\mathrm{i}$ den augustinske tradition hænger sammen, båret af ternarer, de treheder i skaberværket, der spejler Guds trinitet og genfindes i den menneskelige sjæls gudbilledlighed. Jørgen Pedersen fremhæver $\mathrm{i}$ den forbindelse, hvorledes den platoniske skelnen mellem Guds almagt, visdom og godhed i Augustins eftertid indføjes i rækken af ternarer og "præger så store områder som skabelses-metafysikken og gudsbilledets psykologi såvel som analysen af verdenserkendelsen som vej til gudserkendelse og beskrivelsen af åndens indre forhold til Gud* (Visdommens veje, 65).Jørgen Pedersen viser, hvorledes denne ternar overlever gennem oplysningstiden, hvor dens oprindelige, trinitariske præg afstrejfes. Af særlig interesse for Grundtvig-forskningen er Jørgen Pedersens påvisning af, hvorledes ternaren kan genfindes i Grundtvigs salmedigtning (GSV $I, 62$; GSV $V, 126$ ), ligesom Grundtvigs lære om skaberordet kan læses i forlængelse af det augustinske visdomsbegreb. Her er det Jørgen Pedersens pointe, at Grundtvig forener sin skabelsesmetafysik med en affektiv tilgang til Gudsordet, en fremhæuelse af den kristo-centriske kærlighed som den „dybe Sammenhæng , der fører tilbage til den cisterciensiske mystik som den nok væsentligste strømning indenfor middelalderens spiritualitet.

Jørgen Pedersen har viet en hel afhandling til Grundtvigs gendigtning af den cisterciensiske hymne Salve, mundi salutare.

Cisterciensermystikken tolker Jørgen Pedersen som et led i middelalderens augustinsk inspirerede inkarnatoriske sammentænkning af visdomsbegrebet of illuminationslaeren. Det enkelte menneskes sjæl oplyses ligesom Kristi menneskelige sjal af den uskabte visdom* (Visdommens veje, 65), men der findes i mennesket også wen skabt visdom , der gennem den inkarnatoriske enhed med den uskabte visdom vokser til lighed med Kristus. Jørgen Pedersen fremhaver, at denne *menneskelige visdom $\mathrm{i}$ dens totalitet* (Visdommens veje, 68) ved wsamtidig...at vare et forhold til tyset og sandheden og til den evige form tillige omfatter den praktiske erfaring og følelsens forenende fylde * (Visdommens veje, 68). Følelsesaspektet, »den emotionelt-eksistentielle side af forholdet, kær- 
ligheden, viljen, følelsen og den åndelige erfaring « (Visdommens veje, 68) bringes ifølge Jørgen Pedersen til fuldt flor inden for den cisterciensiske tradition, dvs. i Bernhard af Clairvaux's følgeskab. Jørgen Pedersen begrænser sig imidlertid ikke til at belyse Grundtvig i forhold til denne tradition alene, men indleder sin gennemgang med at placere Grundtvigs gendigtninger af middelaldersalmer inden for romantikken, idet Grundtvig i overensstemmelse med den grundlæggende romantiske tankefigur formår at forene det absolutte med den konkrete, jordiske eksistens og - $i$ forlængelse og transformation af illuminationsbegrebet - det enkelte menneskes bevidsthed med den guddommelige bevidsthed. I denne forening mødes den individuelle følelse og den altomfattende, guddommelige visdom i kraft af kærlighedsbegrebet.

Jørgen Pedersen fremhæver, hvorledes det hymniske forlæg har centrum i kærligheden, den størrelse, der i middelalderens spiritualitet forener "den spekulative såvel som den affektive mystiske tænkning og fromhed « (Fra Augustin, 177). Romantikken knytter ifølge Pedersen netop til ved dette kærlighedsbegreb, samtidig med, at kærlighedsbegrebet i romantikken evner at »fastholde en ny subjektivitet ( Fra Augustin, 177), skabe en ny syntese af den altomfattende, enhedsskabende kærlighed og selvet. I Grundtvig nærmer den cisterciensiske, middelalderlige kærlighedsopfattelse og romantikkens kærlighedsbegreb sig hinanden uden at smelte sammen. Forbindelsen mellem metafysik og følelse, lys og kærlighed, udmærker den cisterciensiske kærlighedsmystik, og Jørgen Pedersen ser her både romantikken og Grundtvig som cisterciencerspiritualitetens arvtagere. Trods denne kontinuitet er Jørgen Pedersen bevidst om romantikkens grundpræg som subjektivitet, og han betoner derfor, at Grundtvig i sin romantiske overtagelse af det cisterciensiske traditionsgods i overensstemmelse med den middelalderlige spiritualitets grundpræg når til en harmonisk forening af følelse og tanke, subjektivitet og skabelsesmetafysik. Den augustinske, kristologisk og trinitarisk bestemte visdomsforståelse forener *tilværelsesforklaring og gudsforhold« (Fra Augustin, 195). Netop fordi Jørgen Pedersen her overbevisende afdækker kontinuiteten mellem Grundtvig og en linje i den europæiske tænknings historie, åbnes læserens øje for indsigten i den metafysiske linje i Grundtvigs forfatterskab. Det er - idet vi ikke glemmer Jørgen Pedersens forgængere i salmeforskningen - Jørgen Pedersens fortjeneste, at man som leser af Grundtvigs salmer bringes til indsigt i, hvorledes den Grundtvig, der fremstår og opfattes som den mest danske af alle danske forfattere, i kraft af sin kirkehistoriske tilgang til traditionens tanker og hymnedigtning også kan tolkes i en starre, europæisk, of med Grundtvigs egne ord, »universalhistorisk « sammenhang. 